\title{
Can cognitive behavioral-therapy increase the quality of life and self-efficacy in rheumatoid arthritis patients?
}

\author{
Rahmania Qurrota A'yun, ${ }^{1}$ Nurul Hartini ${ }^{2 *}$ \\ 1,2Faculty of Psychology, Universitas Airlangga, Surabaya - Indonesia
}

\begin{abstract}
Rheumatoid arthritis is a chronic autoimmune illness rarely found in Indonesia. The sufferers mostly are women. This illness affects both the physical and psychological conditions of the sufferers. The symptoms appear almost every day and can cause permanent disability, and even death. It disrupts the quality of life and daily activities of the sufferers, as well as decreases their self-reliance in trying to curing the illness. The provision of cognitive-behavioral therapy is expected to increase their quality of life and self-efficacy. The method used in this study was a single case experiment with a single-subject A-B design. Visual analysis was used to analyze the data. The results showed that the quality of life and self-efficacy of the three subjects increased with the effect size score of 0.8 . The women with rheumatoid arthritis had improved knowledge about their illness, decreases in pain, fatigue, and relapses; increased ability to manage the symptoms of the illness; and confidence that they could do their daily activities better.
\end{abstract}

Keywords: cognitive behavioral therapy; quality of life; self-efficacy; rheumatoid arthritis

\begin{abstract}
Abstrak: Rheumatoid arthritis adalah penyakit autoimun kronis yang jarang ditemukan di Indonesia. Sebagian besar penderitanya adalah perempuan. Penyakit ini mempengaruhi kondisi fisik dan psikologis penderita. Gejalanya muncul hampir setiap hari dan dapat menyebabkan cacat permanen, dan bahkan kematian. Ini mengganggu kualitas hidup dan kegiatan sehari-hari penderita, serta mengurangi rasa percaya diri untuk sembuh dari penyakitnya. Pemberian terapi perilaku kognitif diharapkan dapat meningkatkan kualitas hidup dan efikasi diri mereka. Metode yang digunakan dalam penelitian ini adalah percobaan kasus tunggal dengan subjek tunggal desain A-B. Analisis visual digunakan untuk menganalisis data. Hasil penelitian menunjukkan bahwa kualitas hidup dan efikasi diri dari ketiga subjek meningkat dengan skor efek ukuran 0,8. Para wanita dengan rheumatoid arthritis menunjukkan peningkatan pengetahuan tentang penyakit mereka, mengurangi rasa sakit, kelelahan, dan kekambuhan; peningkatan kemampuan untuk mengelola gejala penyakit; dan keyakinan bahwa mereka dapat melakukan kegiatan sehari-hari dengan lebih baik.
\end{abstract}

Kata Kunci: cognitive behavioral therapy; kualitas hidup; self-efficacy; rheumatoid arthritis

\footnotetext{
*Corresponding Author: Nurul Hartini (e-mail: nurul.hartini@psikologi.unair.ac.id), Faculty of Psychology, Universitas Airlangga, Jl. Airlangga No. 4-6, Surabaya 60286, Indonesia.
} 


\section{Introduction}

Rheumatoid arthritis is a chronic autoimmune disease, characterized by swelling, pain, and damage on the synovial joints as well as fatigue (Aletaha et al., 2010). The prevalence is 0.20 - 0.30 per 100 people in Indonesia and most who suffer from the condition are women. These symptoms inhibit daily activities, such as limited movement. Additionally, the impact extends to others. For instance, the person with the condition will have difficulty carrying and moving objects and will need help (Liu, Xu, Xu, \& Wang, 2017; Whalley, McKenna, de Jong, \& van der Heijde, 1997). The impact will disrupt the overall quality of life of patients, with factors such as stress, sleep difficulties, lowered concentration, and decreased self-esteem affecting interpersonal relations. (Liu et al., 2017; Revenson \& Felton, 1989; Smolen, Aletaha, \& McInnes, 2016). As they become more stressed there is an increased likelihood they will more easily suffer from comorbid other chronic diseases (Revenson \& Felton, 1989).

Chen, Chen, Chen, and Lai (2017) mentioned that among sufferers of ankylosing spondylitis, rheumatoid arthritis, and systemic lupus erythematosus, the rheumatoid arthritis sufferers had the lowest quality of life in terms of health. They are not sure whether the physical condition will be recovered or remain unhealthy.

Quality of life itself is a personal perception of the position in the cultural context in which individuals live and in their relationship with targets, hopes, values, and interests (WHOQOL in Barofsky, 2004). WHO outlines that the domains of quality of life include physical health, psychological health, social relations, and environment. Quality of life plays an important role in optimizing the medical treatment given to patients. In its implementation, what is required is a multidisciplinary approach that includes psychological treatment (Hussein, 2017; Perhimpunan Reumatologi Indonesia, 2017).

A psychological concept that has a great influence on patients with rheumatoid arthritis is self-efficacy (Szotek, 2010). Self-efficacy is an individual's belief in achieving the desired goal (Coty, Salt, Myers, \& Abusalem, 2017). An individual's perception of his/her ability can influence behavior, motivation, thought patterns, and emotional reactions in severe situations. Their level of motivation, feelings, and responses are often based on a subjective view of a situation rather than an objective assessment of their abilities. Therefore, encouraging them to think about the cause and effect of the action to be taken. The current level of self-efficacy of patients with rheumatoid arthritis can predict their future health status (Hewlett, 2001) in patients with rheumatoid arthritis also an important part of achieving remission.

An intervention that has been proven to be able to improve psychological conditions in people with chronic diseases is the cognitive-behavioral therapy (CBT) approach (Beck, 2011). This approach provides positive changes both physically and psychologically in patients who have just been diagnosed with rheumatoid arthritis (Sharpe, Sensky, Timberlake, Ryan, et al., 2001). CBT is a psychological intervention that is considered adaptive and effective in reducing pain, including physical disability and joint dysfunction (Sharpe, Sensky, Timberlake, Allard, \& Brewin, 2001). Of course, this approach is carried out along with medical treatment. This intervention focuses on helping patients balance their daily activities, as well as helping set behavioral and emotional goals to be achieved. Besides, CBT can control pain, contribute to the changes in attitudes and beliefs fundamentally due to the illness, overcome thoughts of being incapable, and improve quality 
of life (Ottonello, 2007; Sharpe, 2013). Furthermore, research by Situmorang, Wibowo, \& Mulawarman (2018) concluded that CBT is effective in increasing students' self-efficacy. Selfefficacy and emotion regulation emphasizes the existence of happiness in students (Alfinuha \& Nuqul, 2017). Therefore, it is expected that the cognitive behavioral therapy approach can improve the quality of life and self-efficacy in patients with rheumatoid arthritis.

\section{Method}

This was a single-case study using an A-B design, where the baseline phase $(A)$ was undertaken before the intervention, and the second phase (B) was after the intervention phase. The baseline period was carried out at three different times, while the intervention period encompassed seven separate sessions. The participants were asked to complete two measuring scales before and after the intervention.

The independent variable in this study was cognitive behavioral therapy, while the dependent variables were quality of life and self-efficacy. The participants were chosen using purposive sampling. For inclusion criteria, the study participants needed to be: female and with a diagnosis of rheumatoid arthritis; members of the autoimmune community; at the productive adult age ranging from 18 to 65 years; possessing an average intellectual ability as evidenced in the results of psychological tests; and dwelling in Surabaya, Indonesia, and willing to be a participant in the study.

The intervention session was conducted using Beck's cognitive-behavioral therapy (CBT) guide, which had been modified with CBT components especially for rheumatoid arthritis sufferers (Sharpe, Sensky, Timberlake, Ryan, et al., 2001). This modification took the form of an individual program between therapist and client. The intervention session included an education component and self-management skill component, consisting of disease-related education, relaxation training, and attention sharing, goal planning, pacing activities, problem-solving skills, cognitive restructuring, assertiveness, and communication, as well as management of flares or risky situations.

There were two measuring scales used: the Quality of Life-Rheumatoid arthritis Scale (QoLRA); and the Rheumatoid Arthritis Self Efficacy Scale (RASE). QoLRA was used to assess the level of quality of life in rheumatoid arthritis patients. This measuring instrument was developed by Danao, Padilla, and Johnson (2001) with a reliability coefficient of $0.87-0.90$. The measuring instrument consists of 8 questions by giving a value from 1 to 10. The higher the score, the better the quality of life. There are 5 domains measured on this scale: the aspect of physical function (elements of physical ability and pain); social functions (elements of interaction and support from family/friends); psychological functions (elements of tension and mood); arthritis; and health.

The Rheumatoid Arthritis Self Efficacy Questionnaire (RASE) is used to measure the level of self-efficacy in patients with rheumatoid arthritis. This measuring instrument was developeded by Hewlett, (2001) from the rheumatology division of universities in the UK, with a reliability coefficient of 0.889 . This measuring instrument consists of 28 questions, with a choice of multilevel answers strongly disagree, disagree, neutral, agree, and strongly agree. The domains measured are aspects of symptoms (pain, fatigue, stiffness), functional limitations, social or lifestyle limitations (relationships with others, fun activities, and sports), disease management strategies (relaxation, sleep, and treatment), dealing with stress emotional, and general approaches to arthritis (such as finding 
ways to deal with problems, looking for suggestion/advice). The results of both measurements were then analyzed using visual analysis. Then, an effect size test was performed to determine the effectiveness of treatment on one variable against the other variables, through statistical tests with Wilcoxon sign-ranked test.

\section{Results}

\section{Subject 1}

Subject 1 showed an increase in both the quality of life and self-efficacy scores. These shifts in scores indicated a positive progression and the changes tended to be stable. During the intervention process, this woman reported a decrease in pain intensity after being introduced to relaxation techniques. Her perception of the disease shifted from the behavior of trying to be sincere and patient in accepting the illness, to that of trying to think positively in dealing with the illness. At first, she thought that the swelling on her body made her completely unable to move. After the intervention, she felt that she was still able to do activities despite being limited. She said she often felt being disturbed by the pain because it disrupted her daily activities. Nevertheless, as a result of the intervention, she was able to think that the pain actually could be overcome by managing stress. She reached a point where she was able to persist with activities despite the pain. The pain was ameliorated by doing 'fun' activities, such as listening to the radio, music, or even communicating with family and close friends.

\section{Subject 2}

In the subject 2, there was a significant and positive increase in her quality of life and selfefficacy scores after completing the intervention sessions. The relaxation techniques, rest management, and also socializing with friends, she said that she is helped reduce the intensity of the pain she felt. At first, she kept complaining about her psychical condition. After the intervention was given, she interpreted the illness and pain she suffered as something that needed to be appreciated and enjoyed. The subject also understood ways to deal with the pain such as by starting a healthy lifestyle through exercise, managing diet patterns, and establishing communication with close friends. The subject who initially often refrained when having problems with her family, eventually learned to be more indifferent and to communicate with people who could understand and were able to overcome the problems similar to what she was experiencing.

\section{Subject3}

Subject 3 demonstrated a score increase positively and stably on the aspects of quality of life and self-efficacy scales. The interventions assisted her to control the pain and she felt so she could move like a healthy person in general. She revealed that the pain still often bothered her but she paid no attention to it by taking medication, focusing on doing activities, and resting when she got tired. At first, she often thought about the problems she faced, but after the intervention and direction from the doctor, she was able to replace the negative thoughts with more positive ones. For example, she felt that she was unable to overcome her family's financial problems but after going through a problem-solving session, she was able to think that she still could have ways to increase family finances. The subject also interpreted the pain she felt was strength from God, so that it made her more enthusiastic and happier, hoping that other people would also be cheerful when seeing her.

The effectiveness test on the quality of life variable obtained a score of 1.542 , while the selfefficacy variable obtained a score of 1.539. Both variables met $X>0.8$, which were in the category of 
high scores. It means that the effect of the CBT on the quality of life amongst these participants is in the 'high' category. Based on the above descrip- tion, the results showed that CBT can improve the quality of life and self-efficacy in women with rheumatoid arthritis.

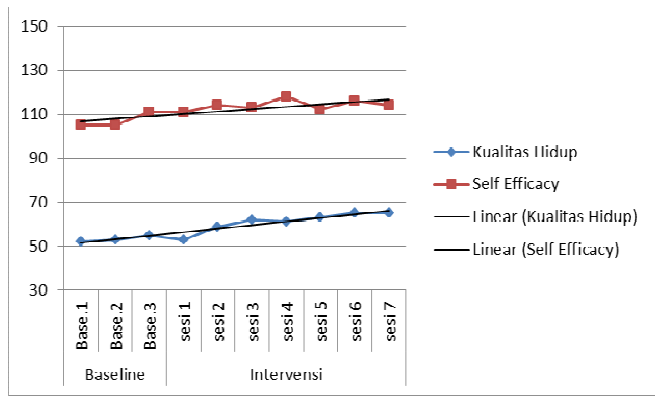

Graphic 1.

Scores of the Quality of Life and Self-efficacy of Subject 1.

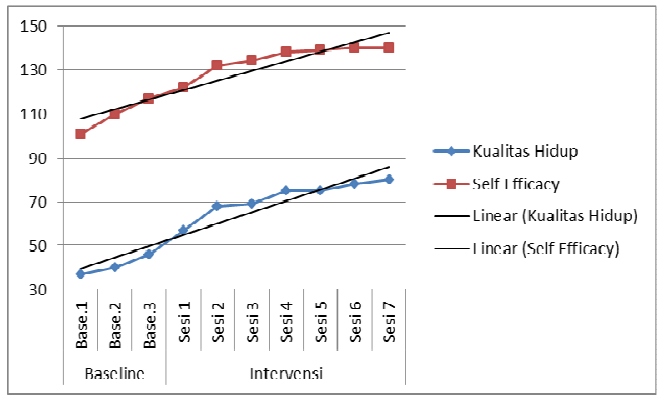

Graphic 2.

Scores of the Quality of Life and Self-efficacy of Subject 2

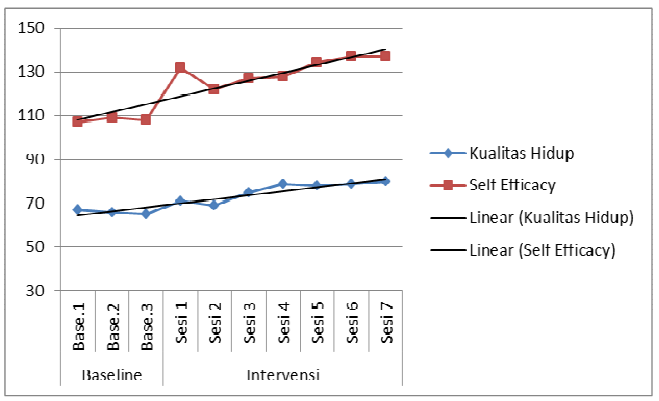

Graphic 3.

Scores of the Quality of Life and Self-efficacy of Subject 3 
Table 1.

Statistical Result of Wilcoxon Signed Ranks Test

\begin{tabular}{ccc}
\hline & QoLRA_posttest - QoLRA_pretest & RASE_posttest - RASE_pretest \\
\hline Z & $-2,670^{\mathrm{a}}$ & $-2,666^{\mathrm{a}}$ \\
Asymp. Sig. (2-tailed) & .008 & .008 \\
\hline
\end{tabular}

a. Based on negative score

Table 2.

Results of Effect Size

\begin{tabular}{ccc}
\hline & Quality of Life & Self-efficacy \\
\hline$Z$ & 2,670 & 2,666 \\
$N$ & 3 & 3 \\
$r$ & 1,542 & 1,539 \\
\hline$Z$ = score $Z ; N$ = number of samples; $r$ = effect size
\end{tabular}

\section{Discussion}

Cognitive-behavioral therapy has been demonstrated in this study to have the potential to improve the quality of life and self-efficacy in people with rheumatoid arthritis. The above graphs show a progressive increase in both measures and for all three subjects throughout the intervention. The objective of this study was to obtain a significant improvement in the subjects' quality of life and self-efficacy. The results demonstrate that this objective was met. The results of the effectiveness test showed a score of 0.8 , which denotes that the CBT had a major effect on the variables of self-efficacy and the quality of life of the subjects. Therefore, it can be concluded that the quality of life and self-efficacy significantly increased after CBT was given.

The CBT approach aims to help sufferers develop adaptive coping strategies and increase confidence in their ability to overcome problems related to their illness (Sharpe, Sensky, Timberlake, Ryan, et al., 2001). Self-management has also proven effective in strengthening coping self-efficacy as well as in reducing anxiety and depression in patients with rheumatoid arthritis (Garnefski et al., 2013). CBT is an adaptive and effective technique of intervention to support rheumatoid arthritis patients because it can help reduce pain, physical disability, and joint function (Sharpe, Sensky, Timberlake, Ryan, et al., 2001). Self-management exercises included in CBT in this study had a positive effect on the subjects' health status. Initially, the subjects reported symptoms such as worsening pain and swelling but these lessened after being given the skills of relaxation and of balancing the time between being active and resting. The CBT component proposed by Sharpe, Sensky, Timberlake, Ryan, et al., (2001) is an individual program between therapist and client, which includes an educational component and a component of self-management skills. The entire contents of the intervention include education about the illness, relaxation training and attention sharing, goal planning, pacing activities, problemsolving skills, cognitive restructuring, assertiveness and communication, and management of flares or risky situations. The combination of these interventions has been seen to bring about significant 
changes to the self-efficacy and quality of life of rheumatoid arthritis sufferers.

This approach facilitated the subjects to perform self-management activities that could overcome the symptoms they felt. Rheumatoid arthritis disrupts movement and makes the patients easily tired, thus leading to feelings of helplessness (Whalley et al., 1997). Nevertheless, These skills can reduce the symptoms of fatigue experienced by Riemsma et al. (1998). CBT has also been shown to reduce the perception of pain in rheumatoid arthritis sufferers through relaxation techniques (Sartika, Setyoadi, \& Widastra, 2009). Additionally, all of the subjects reported that this technique also gave them more relief and feel comfortable.

Psychologically, the subjects reported being happier and less tense when the symptoms appeared. According to them, their stress was what triggered the emergence of negative thoughts and often lead to a relapse. Changing maladaptive thinking helped them to adapt to their minds. CBT has been proven to reduce the perception of pain in rheumatoid arthritis sufferers through relaxation techniques (Sartika et al., 2009). Based on the subjects' subjective experiences, they feel more comfortable and relieved after completing the relaxation techniques. The scheduling of one-week fun activities also increased positive emotions in all subjects.

In terms of general health, the subjects were each able to set a schedule to reduce the impact of pain, The schedule included setting their time for having enough rest, doing fun activities, light exercise or muscle stretching managing thoughts, and also doing relaxation exercises. They were also able to manage a medication schedule and maintain their diet by choosing healthy foods and taking supplements or anti-inflammatory foods. In terms of social functioning, the subjects denoted evidence of being more assertive and able to share the problems they faced with their families, close relatives, or friends of a community, and to share their problems as well as consults the solutions with experts. All the three subjects felt that the skills given had increased their confidence in hoping to immediately achieve remission or stabilize their conditions.

CBT interventions also enhance self-efficacy by targeting subjects' performance experiences to increase expectations of results. All three subjects had the opportunity to try self-management techniques through role-play and other assignments. Self-conducted experiences tend to have a positive effect rather than merely observing (Bandura, 1978). As a result, an increase in selfefficacy scores of the subjects increased their motivation to perform the same skills in the following days to overcome the symptoms they experienced. Bandura (1978) stated that the higher the expectation of results is, the higher the possibility of a task is being fulfilled. The success of the subjects in applying self-management skills was effective in increasing their confidence to be able to cope with the symptoms of illness and daily problems in the future.

The progress of the first subject tended to be stable compared to other subjects. It is highly likely because she had suffered from rheumatoid arthritis longer than the other two, who had been diagnosed with the illness for a year. Lindroth, et al., (1995) stated that older patients with this condition tended to be less active in exercising and trying to protect their joints. Nevertheless, the longer the time they endure suffering, the more they struggle to deal with symptoms and illness. This can result in taking large doses of pain relievers and anti-inflammatory drugs. This subject also actively undertook exercises after a long time not doing this. 
The provision of education about the illness and the role-playing of self-management techniques can add new experiences that are more adaptive to themselves (Beck, 2011). Cognitive techniques given can change the way of thinking to be more logical and positive concerning pain. For example, when the subject 1 experienced vertigo and back muscle pain, she considered those as usual happenings due to fatigue. Although anxiety emerged, the subject immediately took action to ease it by taking a rest and medication if needed. The consequences were less vertigo and pain, and feelings of happiness and composure because she could carry out activities as usual. By doing these techniques, she was also able to overcome the condition of having swollen feet. At first, she interpreted the condition as a threat, but she was able to patiently wait for the next scheduled to see her doctor by doing fun activities. Finally, after being given an injection by her doctor, the swelling decreased and she stated that she felt very happy.

Cognitive techniques helped subject 1 deal with anxiety about her child. She was worried that her child would also develop rheumatoid arthritis. However, the evidence question given to her eased the burden on her mind because there was no medical evidence her child had the condition and the child was simply tired. Thus, she gave her child paracetamol and sterile milk only when the child felt pain all over the body and got tired. She was also increasingly convinced that she was able to deal with back pain and vertigo by avoiding tiring activities, managing her time for breaks and activities, and regularly stretching her muscles to avoid stiffness in the joints.

Performance experience contributes to the likelihood a person will repeat an activity. As for performance experience increases, the expectation of the result also increases (Bandura, 1997).
Consequently, after finishing the CBT session, the subjects tend to repeat some of the techniques that have been learned to solve their problems in their daily activities.

Subject 1 appeared much more intrinsically motivated in seeking ways to improve her health. Her willingness to be involved in this intervention showed that she was also willing to take responsibility for her health. The CBT provided scheduled relaxation, muscle stretching, and rest management skills, thus increasing the chance for her to manage those activities previously mentioned. Eventually, her performance experiences and expectations of the results increased. This made her try these skills every day and complete them even though she had been hampered by work and obligations to spend some time with family. As a result, the change in the self-efficacy score of subject 1 was not as high as that of other subjects. This successful experience increased her self-efficacy and expected behavior changes. After being given $\mathrm{CBT}$, the subject was more intent in stretching muscles, controlling rest periods, and increasing fun activities.

Regarding subject 2, the provision of education and CBT techniques was very helpful in the process of self-management against the disease. The educational process and role-play used in the treatment of rheumatoid arthritis can add new experiences that are more adaptive (Beck, 2011). The subject was able to implement CBT techniques provided in daily activities, such as being able to manage the pain by stretching muscles, relaxing, balancing activities with rest, doing fun activities, and more actively looking for people who were more able to help her solve her problems. As a result, the symptoms reduced and there was no evidence of a relapse during the period of intervention. 
The subject often complained of the pain on her spine that seemed to be continual. She perceived this pain as a threat and she was less able to accept the condition, even though her doctor had given opioid drugs as a pain reliever. She wondered why the pain did not subside, even though every day she did exercise and took medication regularly. As a result, she became increasingly anxious and felt more pain as she reflected on her situation. The providing of decatastrophizing ${ }^{1}$ questions and problem-solving questions helped her discover new solutions, including the management of rest, and relaxation techniques to relieve the pain. These strategies were used every day, thereby increasing her experience of performance and outcome expectations. This convinced her to do them again for the same problem later on. As a consequence, she reported an increase in positive emotions, such as happiness, and enthusiasm to do daily activities that also increased her motivation to get healthier.

As a religious individual, she was submissive to God so that she always prayed every time she got in trouble. Spiritual health locus of control is classified as an internal aspect in which an individual actively looks for ways to improve the state of their health by habitually praying and trying to get closer to God (Clark, Williams, Huang, Roth, \& Holt, 2018). The subject believed that God will help her if she tries and prays. By using CBT, she got the opportunity to try to improve her selfmanagement skills to improve experience performance and produce positive results. Later on, she scheduled time to practice these skills repeatedly and raised her expectations of having a quality life in the future. The expectation of high

${ }^{1}$ Decatastrophizing is a cognitive restructuring technique to reduce or challenge catastrophic thinking. The term 'decatastrophizing' was coined by Albert Ellis (1962) who developed REBT, but as a technique it is equally at home within a CBT model (Psychology Tools, n.d.). results made her complete all the homework given to her during the intervention process. This dramatically increased her confidence and she provided clear evidence of the benefits of selfmanagement strategies.

Subject 3 also attested the benefits of CBT techniques for reducing the symptoms of rheumatoid arthritis. The education process and role-play added to her knowledge about the disease, so that when she felt pain in her wrist and intense tingling, she was able to overcome them by taking medication and stretching the muscles. She also thought that these symptoms were common in people with rheumatoid arthritis. After the interventions, she reported that additional knowledge and using these new techniques made her feel 'better' and 'happier.'

Problem-solving skills help individuals to set an agenda of what they need and what they need to do to overcome problems and challenges (Beck, 2011). The problems faced by the subject 3 were about family relations and financial condition. She often ran out of money and had to find ways to increase income. She felt reluctant to borrow money from her first child who had worked to cover her family's financial shortcomings. However, it was the only effective way to get money in a short time, which made her anxious. Then, the subject was given evidence question, which showed that the child did not mind if she would borrow money and the salary of her child was always given to her initially to meet the family's financial needs. Consequently, she agreed to this and said that it was not a problem borrowing money because it would be returned immediately, as the money belonged to the child. She felt relieved after thinking that way and in the following month, she was less anxious about borrowing money from her child.

Internal health locus of control in the subject contributed to creating a sense of responsibility 
towards her health. She was a person who was eager to look for information about how to handle the disease she suffered so that when this intervention was offered to her, she accepted it without question. All CBT techniques that were carried out by her gave positive results, such as decreased stiffness, a happier mood, and being able to think more positively about herself. This had the effect of increasing her expected results and performance experience so that she completed all the required homework, and her positive emotions increased and symptoms decreased. Finally, she became more confident that she could solve their problems in the future (i.e., emotional problems, dealing with distress and social relationship problems, and others' expectations) by using the CBT techniques that had been taught to her. After the intervention, she also perceived the disease as a gift from God, and she said she felt more grateful and happier.

\section{Conclusion}

Based on the results and discussion above, it can be concluded that cognitive-behavioral therapy was effective in improving the quality of life and self-efficacy of the research subjects who suffered from rheumatoid arthritis. The effectiveness of cognitive-behavioral therapy on self- efficacy and quality of life in this study was categorized to have a large impact. Cognitivebehavioral therapy could improve the quality of life of the subjects in the four domains of quality of life i.e. physical health, psychological health, social relations, and environment, through changing maladaptive thinking to be more adaptive, and learning self-management techniques to overcome pain. Cognitive-behavioral therapy also increased the subjects' self-efficacy by increasing performance expectations through role-playing self-management skills, leading to an increase in expected results. Increased expectation of this result motivated the subjects to finish the homework so that self-efficacy increased and the desired behavior changes occurred.

Based on the result of this study, it appears that there is the correlation between self-efficacy and quality of life in subjects with rheumatoid arthritis. This study could provide a basis for further research with a larger and more diverse sample, and potentially employing a contrasting research methodology. Therefore, further studies related to topics need to be conducted with more appropriate research methods. Measurement of the health locus of control of subjects can also be carried out to obtain richer data.]

\section{References}

Aletaha, D., Neogi, T., Silman, A. J., Funovits, J., Felson, D. T., Bingham, C. O., ... Hawker, G. (2010). 2010 Rheumatoid arthritis classification criteria: An American College of Rheumatology/European League Against Rheumatism collaborative initiative. Arthritis \& Rheumatism, 62(9), 25692581. https://doi.org/10.1002/art.27584

Alfinuha, S., \& Nuqul, F. L. (2017). Bahagia dalam meraih cita-cita: Kesejahteraan subjektif mahasiswa teknik arsitektur ditinjau dari regulasi emosi dan efikasi diri. Psikohumaniora: Jurnal Penelitian Psikologi, 2(1), 12-28. https://doi.org/10.21580/pjpp.v2i1.1357

Bandura, A. (1978). Self-efficacy: Toward a unifying theory of behavioral change. Advances in Behaviour Research and Therapy, 1(4), 139-161. https://doi.org/10.1016/0146-6402(78)90002-4

Bandura, A. (1997). Self-efficacy: The exercise of control. New York: WH. Freeman. 
Barofsky, I. (2004). Reviewed work: Quality of life research: A critical introduction by M. Rapley. Quality of Life Research, 13(5), 1021-1024. https://doi.org/10.2307/4038910

Beck, J. S. (2011). Cognitive behavior therapy basic and beyond (2nd ed.). New York: The Guilford Press.

Chen, H.-H., Chen, D.-Y., Chen, Y.-M., \& Lai, K.-L. (2017). Health-related quality of life and utility: Comparison of ankylosing spondylitis, rheumatoid arthritis, and systemic lupus erythematosus patients in Taiwan. Clinical Rheumatology, 36(1), 133-142. https://doi.org/10.1007/s10067016-3471-y

Clark, E. M., Williams, B. R., Huang, J., Roth, D. L., \& Holt, C. L. (2018). A longitudinal study of religiosity, spiritual health locus of control, and health behaviors in a national sample of African Americans. Journal of Religion and Health, 57(6), 2258-2278. https://doi.org/10.1007/ s10943-017-0548-0

Coty, M.-B., Salt, E. G., Myers, J. A., \& Abusalem, S. K. (2017). Factors affecting well-being in adults recently diagnosed with rheumatoid arthritis. Journal of Health Psychology, 22(4), 493-504. https://doi.org/10.1177/1359105315604887

Danao, L. L., Padilla, G. V., \& Johnson, D. A. (2001). An English and Spanish quality of life measure for rheumatoid arthritis. Arthritis \& Rheumatism, 45(2), 167-173. https://doi.org/10.1002/15290131(200104)45:2<167::AID-ANR170>3.0.CO;2-X

Ellis, A. (1962). Reason and emotion in psychotherapy. New York: Lyle Stuart.

Garnefski, N., Kraaij, V., Benoist, M., Bout, Z., Karels, E., \& Smit, A. (2013). Effect of a cognitive behavioral self-help intervention on depression, anxiety, and coping self-efficacy in people with rheumatic disease. Arthritis Care \& Research, 65(7), 1077-1084. https://doi.org/10.1002/acr.21936

Hewlett, S. (2001). Development and validation of a self-efficacy scale for use in British patients with rheumatoid arthritis (RASE). Rheumatology, 40(11), 1221-1230. https://doi.org/10.1093/ rheumatology/40.11.1221

Hussein, W. A. (2017). The Quality of Life in Patients with Rheumatoid Arthritis in Baghdad, 2017: A Cross-Sectional Study. International Journal of Medical Research \& Health Sciences, 6(11), 2034.

Lindroth, Y., Bauman, A., Brooks, P. M., \& Priestley, D. (1995). A 5-year follow-up of a controlled trial of an arthritis education programme. Rheumatology, 34(7), 647-652. https://doi.org/10.1093/ rheumatology/34.7.647

Liu, L., Xu, X., Xu, N., \& Wang, L. (2017). Disease activity, resilience and health-related quality of life in Chinese patients with rheumatoid arthritis: a multi-center, cross-sectional study. Health and Quality of Life Outcomes, 15(1), 149. https://doi.org/10.1186/s12955-017-0725-6

Ottonello, M. (2007). Cognitive-behavioral interventions in rheumatic diseases. Giornale Italiano Di Medicina Del Lavoro Ed Ergonomia, 29(1 Suppl A), A19-23.

Perhimpunan Reumatologi Indonesia. (2017). Pedoman penapisan dan tata laksana infeksi tuberkulosis laten pada pasien penyakit reumatik yang akan mendapatkan terapi DMARD Biologik. Jakarta: Perhimpunan Reumatologi Indonesia.

Psychology Tools. (n.d.). Decatastrophizing. Retrieved from https://www.psychologytools.com/ resource/decatastrophizing/

Revenson, T. A., \& Felton, B. J. (1989). Disability and coping as predictors of psychological adjustment to rheumatoid arthritis. Journal of Consulting and Clinical Psychology, 57(3), 344-348. https://doi.org/10.1037//0022-006x.57.3.344 
Riemsma, R. P., Rasker, J. J., Taal, E., Griep, E. N., Wouters, J. M. G. W., \& Wiegman, O. (1998). Fatigue in rheumatoid arthritis: The role of self-efficacy and problematic social support. British Journal of Rheumatology, 37(10), 1042-1046. https://doi.org/10.1093/rheumatology/37.10.1042

Sartika, D. D., Setyoadi, S., \& Widastra, N. M. (2009). Pengaruh teknik relaksasi nafas dalam terhadap penurunan persepsi nyeri pada lansia dengan artritis reumatoid. Jurnal Keperawatan Soedirman, 4(2), 46-53. https://doi.org/10.20884/1.jks.2009.4.2.222

Sharpe, L. (2013). Psychological treatment for rheumatoid arthritis works: Now we need to know what elements are most effective and for whom. The Journal of Rheumatology, 40(11), 1788-1790. https://doi.org/10.3899/jrheum.131043

Sharpe, L., Sensky, T., Timberlake, N., Allard, S., \& Brewin, C. R. (2001). The role of cognitive behavioural therapy in facilitating adaptation to illness in rheumatoid arthritis: A case series. Behavioural and Cognitive Psychotherapy, 29(3), 303-309. https://doi.org/10.1017/S1352465801003046

Sharpe, L., Sensky, T., Timberlake, N., Ryan, B., Brewin, C. R., \& Allard, S. (2001). A blind, randomized, controlled trial of cognitive-behavioural intervention for patients with recent onset rheumatoid arthritis: Preventing psychological and physical morbidity. Pain, 89(2), 275-283. https://doi.org/10.1016/S0304-3959(00)00379-1

Situmorang, D. D. B., Wibowo, M. E., \& Mulawarman, M. (2018). Konseling kelompok active music therapy berbasis Cognitive Behavior Therapy (CBT) untuk meningkatkan self-efficacy mahasiswa millennials. Psikohumaniora: Jurnal Penelitian Psikologi, 3(1), 17-36. https://doi.org/10.21580/pjpp.v3i1.2508

Smolen, J. S., Aletaha, D., \& McInnes, I. B. (2016). Rheumatoid arthritis. The Lancet, 388(10055), 20232038. https://doi.org/10.1016/S0140-6736(16)30173-8

Szotek, N. (2010). Rheumatoid arthritis [RA]: More than an inflammatory disorder? A systematic review. University of Twente, Netherlands.

Whalley, D., McKenna, S. P., de Jong, Z., \& van der Heijde, D. (1997). Quality of life in rheumatoid arthritis. Rheumatology, 36(8), 884-888. https://doi.org/10.1093/rheumatology/36.8.884 